International Journal of Library \& Information Science (IJLIS)

Volume 8, Issue 2, May-August 2019, pp. 36-50, Article ID: IJLIS_08_02_005

Available online at

http://iaeme.com/Home/issue/IJLIS?Volume=8\&Issue2

Journal Impact Factor (2019): 9.8614 (Calculated by GISI) www.jifactor.com

ISSN Print: 2277-3533 and ISSN Online: 2277-3584

(C) IAEME Publication

\title{
WORKING EXPERIENCE AND FIELD OF SPECIALISATION AS DETERMINANT FACTORS OF ENGINEERS' UTILISATION OF INFORMATION RESOURCES IN LIBARIES OF PETROLEUM INDUSTRIES IN SOUTH- SOUTH, NIGERIA
}

\author{
Abimbola Labake Agboke \\ University Library, University of Uyo, Uyo, Akwa Ibom State, Nigeria.
}

\begin{abstract}
This study investigated the influence of Petroleum Engineers' personal characteristics as determinant factor on their utilisation of information resources in Libraries of petroleum industries in south-south, Nigeria. The characteristics are working experience and field of specialisation. The survey was guided by three research questions and two hypotheses which were formulated for testing. The population of the study consisted of 1572 engineers in Exxon Mobil, Eket, Akwa Ibom and Agip Oil Company in Port Harcourt. The sample consisted of 499 respondents drawn from petroleum, mechanical, computer, electrical and other engineering fields in Exxon Mobil, Eket and Agip Oil Company in Port Harcourt. A 40-item researcher developed instrument called: Personal characteristic of Engineers and Information Resources Utilisation Questionnaire (PCEIRUQ) was used for data collection. The instrument has a reliability index of 0.95 using Cronbach's alpha coefficient. Data generated were analysed using Analysis of Variance (ANOVA). The results showed that information resources available in decreasing rank order are books, datasheets, project drawing, manuals, reports, CDs, information from colleagues, seminar/ workshops/ conference, internet and maps. Findings indicate that engineers' experience and fields of specialisation have significant $(P<0.05)$ influence on their utilisation of information resources available in the petroleum industries. The table showed that mechanical engineers, with means score of 66.17 use the highest users of available information resources in their respective petroleum industries Libraries. These are closely followed by computer engineers (Mean = 64.12); Petroleum engineers (means $=63.39)$, in deceasing rank order. These observations showed that mechanical, computer and petroleum engineers are the top 3 users of information resources in petroleum industries. Newly employed engineers (mean $=65.89$ ) were also observed to utilise information resources more than their experienced counterparts (mean $=65.53$ ). Recommendations was made that all engineers should
\end{abstract}


Working Experience and Field of Specialisation as Determinant Factors of Engineers' Utilisation of Information Resources in Libraries of Petroleum Industries in South- South, Nigeria

be adequately sensitised on the significance of information in enhancing their productivity in their respective fields. It was also recommended that the engineers should be encouraged to make effective use of available information resources through regular user education programmes and exhibition and display of available information resources.

Key words: Working experience, field of specialisation, Determinant, Engineers, Information utilisation, information resources, Petroleum Industries and South-South

Cite this Article: Abimbola Labake Agboke, Working Experience and Field of Specialisation as Determinant Factors of Engineers' Utilisation of Information Resources in Libaries in Petroleum Industries in South- South, Nigeria, International Journal of Library \& Information Science, 8(1), 2019, pp. 36-50.

http://iaeme.com/Home/issue/IJLIS?Volume=8\&Issue2

\section{INTRODUCTION}

Information utilisation is referred to as the practical and maximum use of library information materials identified and acquired by a user for the purpose of solving a problem. Utilisation varies among individuals, social groups, institutions, government agencies, organizations and establishments. (Emasealu and Popoola, 2016). This corroborates with the opinion of (Goraharper and May, 2013). The ability of utilising proper information is one of the essential clinical skills required by pharmacists to fulfill pharmacist's role as the primary source of drug knowledge.

Over time, the term information need has been used in a variety of ways. Aina, (2004) opined that "every individual whether literate or not, has information needs, which... are critical to survival. Engineers in petroleum industries need adequate and relevant information to perform their duties effectively. Engineers apply the principles of science and mathematics to develop economical solutions to technical problems. Their work is the link between scientific discoveries and the commercial that meet societal and consumer needs. Information will enable engineers to keep current and updates in their fields. Engineers who have not kept current in their fields may find themselves at a disadvantage when seeking promotion or during layoffs. http://www.bmes.org. (2010).

Owing to the nature of job of the engineers they need accurate, timely and relevant information resource to back up their jobs activities. Montgomery, (1992) suggests that for sources to be profitable to the users, they must be relevant to user information and reading needs. Engineers need information to make decision and clear uncertainties in their professional fields. Previous studies (Golden, 1991; Allen, 1996; Anafulu, walamba. 1998: Army, 2010) show that, even with the best information system in place, some problems like discrepancy between the needs of users and the resources can predict or interfere with user utilisation of available resources.

Some personal characteristics of individuals and environment can determine the level of utilisation of available information resources. Chen, (1980) in Oyadeyi, (2014). remarked that the information seeking pattern of an individual is determined by the individual information environment, which consist of: background and characteristics of the individual; the nature and type of information need with which he/she is confronted; the type of availability of information resources, information providers capability in responding to a request and the degree and satisfaction perceived by an individual with the ability of one or more information providers to respond to his/her information needs. Therefore, it important to carry out this study on some factors that determine the petroleum engineers utilisation of available information resources in the libraries of petroleum industries in South - South, Nigeria. 


\section{LITERATURE REVIEW}

The literature review is done on various researches conducted on working experience, fields of specialisation and utilisation of information resources.

\subsection{Working Experience and Utilisation of Information Resources}

The number of years a professional spends on the job more often than not tends to affect the use of information resources. (Jones, 1997) in his contribution was more specific and affirmed that information sourcing and utilisation tend to increase in patrons with longer years of experience in their field. Experience comes from being on the system and interacting with and learning from the circumstances of the system. Adefolaju, (1989) modestly compares the knowledge he had gained as principal for seven years with the grasp of the requirements of the job which he had as a newly appointed principal, and concluded that the difference was too much to be imagined. Otike (1999) investigated the information needs and seeking behavior of engineers he posited that engineers and experienced ones do not require much information for enhancement as the younger and newly qualified ones.

According to Denga, (1996) previous experience or exposure to a system significantly influence attitude and behavior toward any circumstances. Allen, (1996) opined that experience enables users to understand the pattern of resources arrangement in the library, literature searches, retrieval mechanism and enquiry approaches. This will make it easier for the engineers to retrieve information easily than the inexperience ones.

Leekie and Fullerton, (1999) in their study of information literacy in science and engineering undergraduate education students observed that faculty perception was that students who have not learned Library based research at their lower years were unmotivated, uninterested or just poor students. However, their observations showed that students abilities improved considerably by their senior years. The study also found out that students in their third and fourth years have possessed the basic skills in information searching in the Library than those in their first and second years. This implies that utilisation of information resources improved considerably by the years of working experience.

\subsection{Field of specialisation and utilisation of information resources}

The kind of information resources used depend on the information needs of the user. Tindwa, Chawinga and Dube (2019) in used study on information seeking bevaviour of security student discovered that security students need information resources related to criminal and general intelligence. The kind of job one finds himself, location, residence, education, etc determine the kind of information sought. Alegbeleye, (1989) thus a male or female may belong to one user category in one occasion and change to another group in another situation. According to Uwa and Ossai-onah (2013), information needs are varied and continually changing in every field such as social, economy, politics, culture and education. Nevertheless, information is categorised mostly by the information seeking behaviour of the individual in need of information. It involves a set of actions in expressing information needs, information seeking, evaluating and selecting information and finally using this information to satisfy that individual's needs.

However, Baro and others (2010) in their study of the information seeking behaviour of undergraduate students in the humanities in three universities in Nigeria, discovered that the information needs that make the undergraduate students search for information is academic information with the highest rating 233 (93.2\%), followed by personal information with 10 $(4.0 \%)$, and sports information with least rating $7(2.8 \%)$. According to the study, undergraduate students need academic information to write their course assignment, seminar papers, prepare for their class discussions, and prepare for their examinations and tests, and 
Working Experience and Field of Specialisation as Determinant Factors of Engineers' Utilisation of Information Resources in Libraries of Petroleum Industries in South- South, Nigeria

information to write their final year research papers more than any other information such as personal and sports information. In the same vein, Fatima and Ahmad (2008) surveyed the information seeking behaviour of an Indian College Students. The survey findings revealed that $30(50 \%)$ out of the 60 respondents seek for information purposely for career development followed by those who seek for information to solve problems, keep-up-to-date and to write an article or research paper. Also, Ilasariya and Parmar (2012) studied the information need and information seeking behaviour of faculty members and reported that most faculty members needed information for academic work 100, writing papers 50, updating knowledge 30 and research works 20. Uheghu (2007) categorised Library users according to their level of specialisation. Uheghu in his study noted that an educated person may utilise different information from that of an illiterate or semi-illiterate. For instance, while students in the first years of study would seek information on assignments, term papers and how to complete their notes, final year students seek information for their projects, seminars and job opportunities etc.

A study conducted by Rogers (2000) to investigate the information seeking behaviour of interns (resident doctors) at Kenyatta National Hospital, reported than the registrars in general surgery and pediatrics made use of Medical Library more than the residents in other specialties. This she attributed to the fact that they are in the stage of their residency programme and making serious effort towards passing the qualifying examinations.

Igbeka and Atinmo (2002) on information seeking behaviour and utilisation of agricultural engineers, based on their work places. They reported that engineers from the ministry seek information concerning their jobs. Those in private sectors, seek information on how to fabricate machines, while their counterparts in research institutes and tertiary institutions seek academic information for research publication.

An information need and seeking behaviour of medical students in their various years of study was revealed in a study carried out by Adedibu and Adio (1998) indicated that $70 \%$ of the respondents spent 3.8 hours perweek in the library consulting books relevant to the area of their specialisation. Whether or not information needs are pursued, depends on the individual's ability to identify their need and then to express the need in terms that are searchable by themselves or a third party. (Davies, 2007).

Akusu (1987) averred that most researchers made private arrangement such as subscription to journals and purchase of books to keep themselves up to date with relevant information to their field of specialisation. Most engineers are specialised in their respective fields, because of these specialties, they make use of different types of information at a time. Following are details on the seventeen engineering specialties covered in the Federal Government's Standard Occupation Classification (SOC) system. Numerous other specialties are recognized by professional societies, and each of the major branches of engineering has numerous subdivisions. Civil engineering, for example includes structural and transportation engineering, and materials engineering includes ceramic, metallurgical, and polymer engineering (Suite, 2010).

Engineers also may specialised in one industry, such as motor vehicles, or in one type of technology, such as turbines or semiconductor materials. Aerospace engineers design, test, and supervise the manufacture of aircraft, spacecraft, and missile. Those who work with aircraft are called aeronautical engineers, and those working specifically with spacecraft are astronautical engineers. Aerospace engineers develop new technologies for use in aviation, defense systems, and space exploration, often specialising in area such as structural design, guidance, navigation and control, instrumentation and communication, and production methods. They also may specialised in a particular type of aerospace product, such as 
commercial aircraft, military fighter jets, helicopters, spacecraft, or missiles and rockets, and may become expects in aerodynamics, thermodynamics, celestial mechanics, propulsion, acoustics or guidance and control systems. (Joseph, 2010).

Agricultural engineers apply their knowledge of engineering technology and science to agricultural and the efficient use of biological resources. Accordingly, they also are referred to as biological and agricultural engineers. They design agricultural machinery, equipment, sensors, processes, and structures, such as those used for crop storage. Some engineers specialising in area such as power systems and machinery design, structural and environmental engineering, and food and bioprocess engineering. They develop ways to conserve soil and water and to improve the processing of agricultural products. Agricultural engineers often work in research and development, production, sales, or management (Suite, 2010). Due to different area of specialisation of the engineers. they make use of different information resources for their various job specializations.

Haruna and Mabawonku (2001:69), in their study of information behaviour of lawyers in Nigeria, point out that since lawyers have to serve a dynamic clientele, they are expected to deal with a variety of complex legal problems, hence, require access to good legal information. They further argued that in order for lawyers to do this professionally, they need to refer to different sources of information like court decisions, past cases, current legislation and legal policies. Otike, (1999: 19) concludes that lawyers need detailed research information, to positively face the duty of resolving legal problems for different situations and different clients. Mosuro, (2000) in a study observed that information users are varied in their needs and attitudes.

The role of the library therefore is to understand the needs of the users and their attitudes towards seeking their needs. A thorough understanding of these will help in the provision of relevant services to the users.

\section{OBJECTIVE OF THE STUDY}

The main objective of the study is to determine the types of information resources available in the petroleum industries libraries and factors that determines the utilisation of these resources.

The specific objectives of the study are as follows:

1. To examine the influence of working experience of engineers on their utilisation of available information resources in libraries of petroleum industries in South - South, Nigeria.

2. To determine the influence of field of specialisation on engineers' utilisation of information resources in libraries of petroleum industries in south-south, Nigeria.

\section{Hypotheses statement}

1.There is no significant influence of engineers' working experience on their utilisation of information resources in libraries of petroleum industries in South -South, Nigeria.

2. There is no significant influence of engineers' field of specialisation on their utilisation of information resources in libraries of petroleum industries in South - South, Nigeria.

\section{RESEARCH METHODS}

\subsection{Research Design}

The study adopted ex-post-facto research design. The independent and dependent variables had already occurred and the researcher only had to draw inference based on facts already on ground. As noted by Kerlinger (1973), the researcher had no direct control over the independent and dependent variable as both events were not manipulated. 
Working Experience and Field of Specialisation as Determinant Factors of Engineers' Utilisation of Information Resources in Libraries of Petroleum Industries in South- South, Nigeria

\subsection{The Study Area}

South-South geo political zone of Nigeria which comprise of Akwa Ibom, Cross River, Delta, Edo, Rivers and Bayelsa States. The South - South popularly called Niger - Delta region controls the major oil wells of the nation. The area hosts major Petroleum companies like Exxonmobil, Chevron, Agip and Shell Petroleum Company in addition to other subsidiary oil companies and organizations in Eket, PortHarcourt and Warri. These companies have special libraries to cater for the information needs of their engineers. These include the Mobil Records centre in Eket, Oil and Gas pipeline library in Warri and the Shell Petroleum Library in PortHarcourt.

\subsection{Population of the Study}

The population of this study consists of all the 1,572 Engineers in Exxon Mobil Eket and Agip Oil Company in Port Harcourt(PH). The distribution is as shown in Table 1.

Table 1 Distribution of Engineers in Exxon-Mobil and Agip Companies

Petroleum Company

ExxonMobil, Eket

Agip, PH
No of Engineers

997

575

1572

Source: Human resources department of ExxonMobil, Eket and Agip, PH, 2010.

\subsection{Sample Size and Sampling Technique}

The sample of this study is 500 engineers (31.8\% of the target population) drawn from Exxon-Mobil Eket and Agip Oil Company in Port Harcourt. Simple random sampling technique was used for sampling.

Table 2 Sample Frame

\begin{tabular}{lll}
\hline Petroleum Company & Population & Sample \\
\hline ExxonMobil,Eket & 997 & 298 \\
Agip,PH & 575 & 202 \\
\hline Total & 1572 & 500 \\
\hline
\end{tabular}

\section{RESEARCH INSTRUMENT}

A 40-item researcher developed instrument called: personal Characteristic of Engineers and Information Resources utilisation Questionaire (PCEIRUQ) was used for data collection. The 
PCEIRUQ is a 3-part instrument. Part 1 is designed to gather information on the Engineers' personal data. Part 2 is designed to measure the availability of selected information resources in the institutions' libraries. Part 3 is designed to assess the Engineers' utilisation of the available information resources. It is a 4-point Likert-Scale with Always(A), Often (O), Occasionally $(\mathrm{Occ})$ and Never $(\mathrm{N})$ response categories. Always is scored 4 points, Often; 3 points, 0ccasionally; 2 points, Never; 1 point.

\subsection{Validity of the Instrument}

The draft of the instrument, which contained 50 items was submitted to 3 independent assessors who are lecturers in Information and Library Science not below the rank of Senior Lecturer to read, make necessary corrections and other necessary suggestions to ensure the validity of the instrument. Based on their inputs, some of the items were dropped and some were modified. This brought down the number of items from 50 in the draft to 40 in the final form of the instrument.

\subsection{Reliability of the Instrument}

The reliability of the instrument was ascertained using Cronbach's alpha co-efficient. Cronbach's alpha is the most appropriate measure for assessing the reliability of Likert Scale instruments since none of the responses could be said to be right or wrong (Ali, 2006). The instrument used for this study is a Likert Scale, hence the choice of Cronbach's alpha. The questionaire (PCEIRUQ) was administered to 40 Engineers in Exxon-Mobil, Eket and the data collected were analysed using Cronbach's alpha reliability formula:

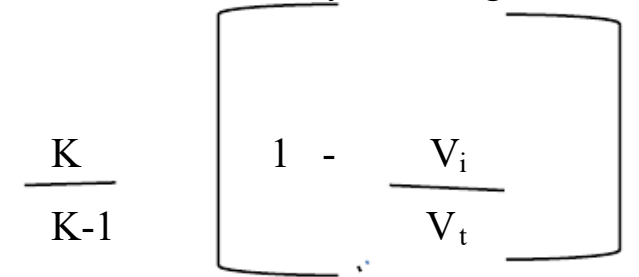

Where $\mathrm{k}=$ no of items, $\mathrm{V}_{\mathrm{l}}=$ sum of variance for individual items, $\mathrm{V}_{\mathrm{t}}=$ sum of variance for all the items. The results showed that the instrument has a reliability index of 0.95 .

\subsection{Administration of the Instrument}

The researcher personally administered the research instrument to the respondents in their respective workplaces. The completed questionnaire collected after a week interval. Personal contact with the respondents allowed the researcher explain certain points to them hence, cut down on mortality rate and invalid responses.

\section{METHOD OF DATA ANALYSIS}

Data collected were analyzed using percentages, independent $t$ - test and analysis of variance (ANOVA) statistics. Mean and standard deviation scores were used to answered all the research questions raised. Independent t-test statistics were used for testing null hypothesis at $\mathrm{P}<0.05$ level of significance.

\subsection{Distribution of Subjects}

A total of 500 copies of the questionnaire were distributed and 499 (99\%) were returned with valid responses. The distribution of the respondents by working experienced and age of engineers is presented in Table 3 .

Table 3 Distribution of Subjects classified by working experience and Field of Specialisation $(\mathrm{n}=499)$. 
Working Experience and Field of Specialisation as Determinant Factors of Engineers' Utilisation of Information Resources in Libraries of Petroleum Industries in South- South, Nigeria

\begin{tabular}{ccc}
\hline Variable/Category & Frequency & Percentage\% \\
\hline Working Experience: $0-5$ years & 119 & 23.8 \\
$6-10$ years & 121 & 24.2 \\
$11-15$ years & 146 & 29.3 \\
16 years and above & 113 & 22.6 \\
Field of Specialisation: Mechanical & 181 & 36.3 \\
Petroleum & 34 & 6.8 \\
Electrical & 105 & 21.0 \\
Computer & 42 & 8.4 \\
Others & 137 & 27.5
\end{tabular}

Table 3 shows that out of 499 respondents: By working experience, 119(23.8\%) were with 0 - 5 years' experience, $121(24.2 \%)$ were with $6-10$ years' experience, $146(29.3 \%)$ were with $11-15$ years' experience and $113(22.6 \%)$ were with 16 years and above experience. By age distribution it shows that $53(10.6 \%)$ were between the ages of $20-23$ years while (89. 4\%) were 24 years and above.

\section{DATA ANALYSIS AND RESULTS}

In this sub section, the descriptive analysis results are presented and used in answering the research questions raised and the results of variance (ANOVA) are also presented and used in testing the hypothesis formulated to guide the study.

\section{Research Question 1}

What information resources are available for engineers in petroleum industries in South-South geo-political Zone of Nigeria? 
Table 4 Frequency and Percentage Responses on Availability of Information Resources $(n=499)$

\begin{tabular}{|c|c|c|c|c|}
\hline \multirow[t]{2}{*}{ Resources } & \multicolumn{2}{|c|}{ Available } & \multirow{2}{*}{$\begin{array}{l}\text { Not } \\
\text { F }\end{array}$} & \multirow{2}{*}{$\begin{array}{l}\text { Available } \\
\%\end{array}$} \\
\hline & $\mathbf{F}$ & $\%$ & & \\
\hline 1. Project Drawings & 481 & 96.4 & 18 & 3.6 \\
\hline 2. Data sheets & 481 & 96.4 & 18 & 3.6 \\
\hline 3. Manuals & 472 & 96.4 & 27 & 5.4 \\
\hline 4. Alignment Sheets & 333 & 66.7 & 166 & 33.3 \\
\hline 5. Reports & 472 & 94.6 & 27 & 5.4 \\
\hline 6. Textbooks & 490 & 98.2 & 9 & 1.8 \\
\hline 7. Journals & 350 & 70.1 & 149 & 29.9 \\
\hline 8. Thesis/Dissertation/Project & 221 & 44.3 & 278 & 55.7 \\
\hline 9. Internet & 394 & 79.0 & 105 & 21.0 \\
\hline \multicolumn{5}{|l|}{ 10. Seminar/Workshop/ } \\
\hline Conference. & 429 & 86.0 & 70 & 14.0 \\
\hline 11. Maps & 367 & 73.5 & 132 & 26.5 \\
\hline 12. Encyclopedia & 297 & 59.5 & 202 & 40.5 \\
\hline 13. Information from Colleagues & 454 & 91.0 & 45 & 9.0 \\
\hline 14. CDs & 464 & 93.0 & 35 & 7.0 \\
\hline 15. Newspapers & 339 & 67.9 & 160 & 32.1 \\
\hline
\end{tabular}

Considering the percentage responses indicating availability of the listed information resources, table 4 shows that the most available resources for engineers in the petroleum industries in the South-South Zone is book with $98.2 \%$ rating. This is closely followed by data sheets and project drawing which jointly take the second position with $96.4 \%$ rating; manuals and reports jointly occupy the 4th position with $94.6 \%$ rating; and CDs take the 6 th 
Working Experience and Field of Specialisation as Determinant Factors of Engineers' Utilisation of Information Resources in Libraries of Petroleum Industries in South- South, Nigeria

position with $93.4 \%$ rating. Information from colleagues occupies the 7 th position with $91.0 \%$ availability rating; seminar/workshop/conferences, the 8 th position with $86.0 \%$ ratings, internet occupies the 9 th position with $79.0 \%$ rating, maps take the 10 th position with $73.5 \%$ rating. Journals take the 11 th position with $70 \%$ rating, while newspapers take the 12 th position with $67.9 \%$ availability rating. Alignment sheet take the 13 th position with $66.7 \%$ rating; encyclopedia the 14th position with $59.5 \%$ rating and thesis/dissertation/projects occupy the 15 th position with $44.3 \%$ rating. These observations show that the top 10 available information resources for engineers in the petroleum industries in the South-South geopolitical Zone of Nigeria are books; data sheet; project drawing; manuals; reports; CDs; information from colleagues; seminar / workshop / conferences; internet; and maps in decreasing rank order.

\section{Research Question 2}

What is the influence of engineers' working experience on their utilisation of information resources in petroleum industries in the South - South, Nigeria?

Table 5 Grand Mean Scores of Engineers' working experience and information Utilisation

\begin{tabular}{lcc}
\hline Working Experience & No of Respondents & Mean \\
\hline $0-5$ years & 119 & 65.89 \\
6 -10 years & 121 & 62.66 \\
$11-15$ years & 146 & 56.21 \\
16 years and above & 113 & 65.53 \\
\hline
\end{tabular}

The results in Table 5 shows that engineers with $0-5$ years' experience are the highest information resources users scoring 65. 89. They are closely followed by those with 16 and above years $($ mean $=65.53), 6-10($ mean $=62.66)$ and $11-15$ years $($ mean $=56.71)$ experience in decreasing order. This observation shows that engineers with $0-10$ and 16 above years of experience are most uses of available information resources in the petroleum industries in South - South zone of Nigeria.

Hypothesis 1: There is no significant influence of engineers' working experience on their utilisation of information resources in libraries in petroleum industries in South -South, in Nigeria. 
Table 6 Analysis of Variance (ANOVA) Summary of Engineers' working Experience and Utilisation of Information Resources

\begin{tabular}{llllll}
\hline Sources $\begin{array}{l}\text { Sum of } \\
\text { Square }\end{array}$ & Df & Mean & f-cal & f-crit & Decision \\
\multicolumn{1}{c}{ Square } \\
Main Effect: & & & & \\
Experience8130.90 & 3 & 2711.63 & 21.54 & 3.82 & Reject $\mathrm{H}_{\mathrm{o}}$ \\
Error & 62307.25 & 95 & 125.87 & \\
\hline Total & 70442.14 & 98 & & \\
\hline
\end{tabular}

In Table 6 , the calculated $\mathrm{f}$ - value, $\mathrm{f}-\mathrm{cal}$, for the main effect of engineers' experience on their utilisation of available resources is 21.54 . while the corresponding critical value at $\mathrm{df}$ 498 and $\mathrm{p}=0.05$, $\mathrm{f}$ - crit is 3.80 . The $\mathrm{f}$-cal is greater than the $\mathrm{f}$ - crit. This observation shows that engineers' working experience exerts a significant influence on their utilisation of available information resources in petroleum industries in South - South, Nigeria. With this observation hypothesis 1 was rejected.

\section{Research Question 3}

How does engineers field of specialisation influence their utilisation of information resources in petroleum industries in the South-South, Nigeria?

Table 7 Grand mean scores on Engineers field of specialisation and their utilization of information resources $(\mathrm{N}=499)$

\begin{tabular}{lcc}
\hline Fields of Specialisation & No. of Respondents & Mean \\
\hline Mechanical & 181 & 66.17 \\
Petroleum & 34 & 63.12 \\
Electrical & 105 & 61.84 \\
Computer & 42 & 64.12 \\
Others & 137 & 56.39 \\
\hline
\end{tabular}

Table 7, shows that mechanical engineers, with means score of 66.17 use the highest users of available information resources in their respective petroleum industries. These are closely followed by computer engineers (Mean $=64.12)$; Petroleum engineers (means $=63.39)$, in deceasing rank order. These observations showed that mechanical, computer and petroleum engineers are the top 3 users of information resources in petroleum industries. 
Working Experience and Field of Specialisation as Determinant Factors of Engineers' Utilisation of Information Resources in Libraries of Petroleum Industries in South- South, Nigeria

Hypothesis 2: There is no significant influence of engineers' field of specialisation on their utilisation of information resources in libraries in petroleum industries in South - South, Nigeria.

Table 8 Analysis of Variance (ANOVA) Summary on Engineers' fields of Specialisation and Utilisation of Information Resources

\begin{tabular}{lllllll}
\hline Sources & $\begin{array}{l}\text { Sum of } \\
\text { Square }\end{array}$ & Df & Mean & f-cal & f-crit & Decision \\
& & \multicolumn{2}{c}{ Square } \\
\hline \\
Main Effect: \\
Field of
\end{tabular}

The results in table 13, show that the calculated f-valve, f-cal for the main effect of engineers' field of specialisation on their utilization of information resources is 15.09; and that the corresponding critical valve, f-crit, at df 499 and $p=0.05$, is 3.34. the f-cal is greater than the f-crit. This observation shows that engineers field of specialisation has a significant influence on their utilisation of information resources. With this observation; hypothesis 2 is rejected.

\section{FINDINGS}

1. Engineers' working experience impacts significantly on their utilisation of available information resources. Engineers with 1-10 years and 16 and above years were observed to make more use of available information resources compared with those with 11-15 years.

2. There is a significant influence of engineers' field of specialisation on their utilisation of available information. Mechanical engineers were observed to be the highest users of information resources followed by computer, petroleum, electrical and other engineers in decreasing rank order.

\subsection{Discussion of findings}

In this sub - section the major findings of the study are discussed in relation to produce reports in the areas investigated following the order of the research hypotheses.

\subsection{Working Experience and Engineers' Utilisation of information Resources}

The finding from the result in Table 5 and 6 showed that working experience is a significant determinant of petroleum engineers' utilization of information resources. Engineers with 0-10 years and 16 and above years were observed to make more use of available information resources. The observed significant influence of working experience directly agree with Jones (1997) assertion that the number of years a professional spends on the job influence use of information resources. 
It is generally assumed that with many years of experience on the same job, professionals have acquired much information they not need much information anymore. However, the inconsistency in the trend of effect of experience on engineers' utilisation of information resources observed in this study indicate that ever after many years of service, professionals still have the urge to seek for information the high level of information resources utilisation by inexperienced engineers observed is attributed to their urge to improve in their skills and reach the peak of their career, that by the order engineers is attribute to their urge to keep abreast with the modern information communication technologies which have completely revolutionised the world of work, and hence, continue to be relevant in their job.

\subsection{Field of specialisation and Engineers Utilisation of information resources}

From the result in tables 7 and 8, it was observed that the engineers field of specialisation exerted significant influence on their utilisation of information resources. Mechanical engineers, made the highest use of information resources followed by computer engineers, petroleum engineers, electrical engineers, and the other engineers not listed, in decreasing rank order. The observation is attributed to the information needs and job demands of the engineers. This is in support with Baro and others, (2010) in their study of the information seeking behaviour of undergraduate students in the humanities in three universities in Nigeria, discovered that the information needs that make the undergraduate students search for information is academic information with the highest rating 233 (93.2\%), followed by personal information with $10(4.0 \%)$, and sports information with least rating 7 (2.8\%). This also concurred with the study of Tindwa, Chawinga and Dube (2019) on information seeking bevaviour of security students, they discovered that security students need information resources related to criminal and general intelligence. Therefore, the kind of information resources uses depend on the information needs of the user.

\section{RECOMMENDATIONS}

- Libraries in petroleum industries should acquire information resources that will meet the information needs of their users.

- Library orientation should be given to the engineers on how to access the resources in the libraries.

- All engineers should be adequately sensitised on the significance of information in enhancing their productivity in their respective fields.

\section{SUGGESTED AREAS FOR FURTHER STUDY}

Similar study should be carried out on utilisation of information resources in another fields and area.

\section{REFERENCES}

[1] Adedibu, L. and Adio, G. (1998). Information Needs and Information Seeking Pattern of

[2] Medical Students at Ladoke Akintola University of Technology (LAUTECH). Ogbomoso: Aslib proceeding. 42(9):232.

[3] Adefolaju, A. (1989). Educational Management and Planning. Ibadan: Shaneson, C.I. Ltd

[4] Aina L O, (2004). Library and Information Science Text for Africa, Third world service Ltd, Ibadan, p. 67. 5.

[5] Aina, L.O. (2004). Library and Information Science Text for Africa. Ibadan: Third World Information Services. P. 60. 
Working Experience and Field of Specialisation as Determinant Factors of Engineers' Utilisation of Information Resources in Libraries of Petroleum Industries in South- South, Nigeria

[6] Aiyepeku, W. O. (1981). Information Utilisation by Policy Makers in Nigeria, Part 1 Assessing Degrees of Information Consciousness. Journal of Information Science. 4(5): 205-210.

[7] Ali, A. (2006). Conducting Research in Education and the Social Sciences. Enugu: Tashiwa, Networks Ltd. p. 45.

[8] Ajidahum, O: C. (1990). Information Needs of Secondary School Teachers in Oyo Town. Unpublished MLS Projects. University of Ibadan, Ibadan.

[9] Akusu, E. A. (1987). Information Needs of Medical Laboratory Technologists and Resources.

[10] Unpublished MLS Projects. Available to them at the College Medicine, University of Ibadan.

[11] Alegbeleye, G. O. (1989). Studies on Users Information Needs. A Critique and Suggestions.Nigerian Library and Information Science Review. 7(2): 1-8.

[12] Allen, B. L. (1996). Information Task Towards Information System, New York: Academic Press.

[13] Anafulu, J. C. (1997). Information Provision in Nigeria: The Role of the National Library in the Next Decade. Paper Presented at a Seminar on Redefining the National Library on Nigeria for the 21st Century Abuja 8th - 12th September. Available at http...// chronicle. Com/prm/weekly v51/14/bo.

[14] Army, S. (2010). Electrical and Electronics Engineers, Available at http://:www.ieeeusa. Available@web page http://www.Computerorg.

[15] Baro, E. E., Onyenania, G. O., and Osaheni, O. (2010). Information seeking behaviour of undergraduate students in the humanities in three universities in Nigeria. South African Journal of Libraries and Information Science, 76(2), 109-117.

[16] Burkett, M. (2010).http:www.dir.state.tx.us/pubs/derm/roles/endnotes.htm.

[17] Chen, Ching-chih (1980) "Citizen information seeking patterns: A New England study,"Simmons Librarian 12: 3-4.

[18] Davies, K. (2007). The information-seeking behaviour of doctors: a review of the evidence.HealthInformation \& Libraries Journal, 24(2), 78-94.

[19] Denga, D. I. (1996). Human Engineering for High Productivity. Calabar: Rapid Educational Publisher.

[20] Emasealu, H. U. and Popoola, S. O. (2016). Information Needs, Accessibility and Utilisation of Library Information Resources as Determinants of Psychological WellBeing of Prison Inmates in Nigeria. Brazilian Journal of Information Studies: Research Trends. 10:2 (2016) 29-46. ISSN 1981-1640. Retrieved, March, 2019.

[21] Fatima, N., \& Ahmad, N. (2008). Information seeking behaviour of the students at Ajmal Khan Tibbiya College, Aligarh Muslim University: a survey. Annals of Library and Information Studies, 55(4), 141-144. Gora-harper M, May JR (2013) Introduction to the Concept of Drug Information. Access Pharm.

[22] Haruna, I., and Mabawonku, I. (2001). Information needs, seeking behaviour of legal practitioners, and the challenges to law libraries in Lagos, Nigeria. International Information and Library Review, 33(1), 69-87.

[23] Igbeka, J. U. and Atinmo, M. I. (2002). Information Seeking and Information Utilisation of Agricultural Engineers in Nigeria Based on their Different places work. Nigerian Librarian 36(1): 10-20.

[24] Ilasariya, P.G. and Parmar, M. D. (2012). Information Need and Information Seeking Behaviour Faculities affiliated Arts Colleges in Hemchandracharya North Gujarat University, Patan. 
[25] International Multidisciplinary e - Journal. Vol. 1 (ix), 2012. Avalable at webpage : www.shreeprakashan.com. Retrieved 5 August,2019.

[26] Jones, N. (1997). Continuing Education for Librarians leeds: Leeds Polytechnices School

[27] of Librarianship.

[28] Joseph, T. (2010). Electrical and Electronics Engineers, Available at web page http:iiwww.ieeeusa.

[29] Kerlinger, F. N. (1964). Foundation of Behavioral Research. New York: Holt, Rinebart and Winston Montgomery, M. (1992). Ways of reading. London: Rout Ledge.

[30] Otike, J. (1999). The Information needs and seeking habits of lawyers in England: a pilot study. International Information and Library Review, 31, 19-31.

[31] Oyadeyi, A. E. (2014). The Information Needs and Information Seeking Behaviour among the Students of Ondo State University of Science and Technology, Okitipupa. International Journal of Digital Library Services. www.ijdls.in (ISSN;2250 _ 1142). Vol.4(1). 2014.

[32] Rogers, R. (2000). The Information use of Doctors in Training: Report from Cairus Library, University of Oxford. Health Libraries review. 17(3):129-135.

[33] Suite, B. (2010). Institute of Electronics and Electrical Engineers IEEE Computer Society. (2010). http://www.bmes.org.

[34] Thindwa, T., Chawinga, W.D. \& Dube, G., (2019). 'Information-seeking behaviour of security studies students: A case study', South African Journal of Information Management 21(1), a1048. https://doi.org/10.4102/sajim.v21i1.1048.

[35] Uhegbu, A. N. (2007). The Information user: Issues and Theme. Okigwe: Whytam Prints.

[36] Uwa, E. O. and Ossai-onah, O. V. (2013). Information needs and seeking behaviour of students two universities in Imo state, Nigeria. Library Philosophy and Practice.Retrieved from http://digitalcommons.unl.edu/cgi/viewcontent.cgi?article=2348\&context=libphilprac

[37] Walamba, A. (1998). Information Service and Health Promotion: what can Libraries Do? Health Educational Journal. 45(3): 85-90. 